\title{
Pola Asuh Orangtua Tentara Nasional Indonesia pada Anak Usia Dini
}

\author{
Cindy Tri Kusumawardani ${ }^{凶}$, Pujiyanti Fauziah ${ }^{2}$ \\ Pendidikan Anak Usia Dini, Universitas Negeri Yogyakarta (1) \\ Pendidikan Luar Sekolah, Universitas Negeri Yogyakarta (2) \\ DOI: $\underline{10.31004 / \text { obsesi.v5i2.620 }}$
}

\begin{abstract}
Abstrak
Penelitian ini bertujuan untuk mengungkapkan penerapan pola asuh orangtua tentara nasional indonesia terhadap perkembangan anak usia 5-6 tahun. Penelitian ini menggunakan pendekatan kualitatif dengan metode deskriptif analisis. Teknik pengumpulan data yang digunakan dalam penelitian ini yaitu wawancara, observasi, dan dokumentasi. Keabsahan data yang digunakan yaitu dengan teknik triangulasi dan kecukupan referensial. Teknik analisis data yang dilakukan dengan teknik analisis data Model Milles dan Huberman. Langkah-langkah dalam teknik analisis data yaitu reduksi data, penyajian data, simpulan. Hasil penelitian menunjukkan pola asuh yang digunakan oleh orangtua Tentara Nasional Indonesia adalah pola asuh authoritarian. Pola asuh ini menjelaskan bahwa pola asuh menggunakan arahan terhadap anak dan komunikasi dua arah sehingga adanya kehangatan di dalam keluarga. Kehangatan dari pola asuh authoritarian memberikan dampak positif bagi perkembangan anak. Perkembangan anak berkembangan sesuai dengan tahapan usia anak. Hal ini terlihat aspek perkembangan anak yang meliputi aspek fisik motorik, kognitif, sosial, dan emosi.
\end{abstract}

Kata Kunci: pola asuh orangtua; tentara nasional indonesa ; perkembangan anak

\begin{abstract}
This study aims to reveal the application of parenting styles of the Indonesian National Army for the development of children aged 5-6 years. This research uses a qualitative approach with a descriptive analysis method. The data collection techniques used in this study were interviews, observation, and documentation. The validity of the data used was the triangulation technique and referential adequacy. The data analysis technique was carried out by using the Milles and Huberman Model data analysis technique. The steps in data analysis techniques are data reduction, data presentation, and conclusions. The results showed that the parenting style used by the parents of the Indonesian Armed Forces was authoritarian parenting. This parenting style explains that parenting uses direction to children and two-way communication so that there is warmth in the family. The warmth of authoritarian parenting has a positive impact on children's development. Child development develops according to the child's age stage. This can be seen from the aspects of child development which include physical, motoric, cognitive, social and emotional aspects.
\end{abstract}

Keywords: parenting style; Indonesian national army; child development.

Copyright (c) 2020 Cindy Tri Kusumawardani, Pujiyanti Fauziah

$\triangle$ Corresponding author :

Email Address : cindytrikusumawardani@gmail.com ( Yogyakarta, Indonesia )

Received 27 June 2020, Accepted 26 September 2020, Published 26 September 2020 


\section{PENDAHULUAN}

Anak adalah karunia yang dititipkan Allah kepada orangtuanya. Anak juga sebagai penerus bagi keluarga. Oleh sebab itu, orangtua perlu mendidiknya supaya menjadi generasi emas. Generasi emas yang dimaksud adalah generasi yang disiapkan untuk menjadikan Indonesia lebih maju (Darman, 2017: 86). Sesuai dengan hal tersebut, mendidik bukan perkara yang mudah. Mendidik adalah upaya memberikan pembinaan bagi anak baik sikap mental dan akhlaknya. Mendidik ini tidak sekedar transfer of knowledge saja tetapi harus didampingi dengan transfer of values. Mendidik anak itu secara keseluruhan baik aspek kognitif, psikomotorik maupun afektif, supaya anak tumbuh menjadi manusia yang berpribadi (Sadirman, 2005: 51). Selain itu, mendidik juga bukan tugas ibu saja melainkan ayah juga turut berperan.

Mendidik anak tidak lepas dari pola asuh yang diterapkan orangtuanya. Hal ini sejalan dengan pengertian dari pola asuh yang menjelaskan bahwa cara interaksi orangtua dengan anak yang meliputi memelihara, perlindungan, dan adanya pengajaran bagi anak (Sanjiwani \& Budisetyani, 2014: 346). Oleh sebab itu, pentingnya menerapkan pola asuh yang baik.

Pola asuh adalah interaksi antara orangtua dan anak yang memberikan dorongan anak guna mengontrol kehidupan anak (Tridhonato \& Agency, 2014: 5). Pola asuh yang diterapkan orangtua memiliki beragam jenis. Jenis pola asuh itu terdiri pola asuh otoriter, authoritarian, dan permisif (Baumrind, 1991: 62). Pola asuh yang diterapkan orangtua tidak lahir begitu saja, melainkan dipengaruh oleh beberapa faktor.

Faktor dari penerapan pola asuh yang diterapkan oleh orangtua yaitu pekerjaan orangtua dan lingkungan tempat tinggal (Subakti, 2012: 9). Hal ini ditemukan pada wawancara awal yang menjelaskan bahwa pekerjaan ayahnya seorang angkatan dan ibunya sebagai ibu rumah tangga. Latar belakang pekerjaan seorang ayahnya yaitu seorang tentara yang bertugas sebagai penjaga, pelindung, dan mempertahakankan keamanan negaranya yang harus siap siaga kapanpun dan dimanapun (Priambudi dkk., 2015: 2193). Keadaan ini membuat orangtua kurang optimal dalam menjalankan tugasnya mendidik dan mengasuh anaknya.

Kondisi tersebut secara jelas ditunjukkan bahwa ayahnya dinas di Kalimantan sedangkan ibunya di Magelang. Jika ada urusan yang mewajibkan istrinya mendampingi suami maka istri akan pergi ke Kalimantan dengan membawa anaknya. Oleh sebab itu, ibunya harus selalu pulang pergi karena memiliki dua kewajiban yaitu mendampingi suami dan mendidik anak yang lain ketika di Magelang. Berdasarkan hal tersebut faktor pekerjaan orangtua dan lingkungan tempat tinggal dapat mempengaruhi pola asuh yang diterapkan di dalam keluarga.

Sesuai dengan pengamatan awal, orangtua lebih memanjakan anaknya. Hal ini terjadi karena anak tersebut sebagai anak bungsu dan jarak kelahiran dengan kakaknya sangat jauh. Namun, berbeda ketika orangtuanya menerapkan pola asuh kepada ketiga kakaknya. Umumnya, seorang tentara memiliki jiwa yang kasatria yaitu gagah, berwibawa, dan disiplin (Priambudi dkk., 2015: 2193). Hal ini akan berpengaruh pada orangtuanya ketika mendidik anaknya karena konsep dirinya telah terbentuk. Orangtua lebih tegas dan disiplin ketika mendidik anaknya hingga sempat memberikan tindakan yang tegas kepada anaknya. Penerapan pola asuh ini juga memberikan dampak bagi anak. Hasil penelitian menunjukkan bahwa menerapkan pola asuh otoritatif perkembangan anaknya sesuai dengan umurnya $(73,3 \%)$, pola asuh permisif perkembangan anak yang sesuai dengan umurnya $(9,1 \%)$, dan pola asuh tidak otoriter perkembangan anak yang sesuai dengan umurnya $(9,1 \%)$ (Budiman \& Harahap, 2015: 199-200). Pola asuh otoritatif yang diterapkan pada anak memberikan dampak anak untuk mandiri, tetapi orang tua harus tetap menetapkan batas dan kontrol. Dampak pola asuh permisif umunya anak menjadi ketegantungan. Selain itu, hasil penelitian menunjukkan bahwa anak-anak yang dibesarkan dari orang tua otoriter bisa menjadi pemalu, penuh ketakutan, menarik diri, dan berisiko terkena depresi. 
Berdasarkan hasil penelitian tersebut orangtua perlu memahami tentang anak usia dini. Anak usia dini yaitu anak yang berusia 0-6 tahun (K. P. dan K. RI, 2003). Usia 0-6 tahun merupakan masa anak mencapai keemasan atau dalam masa peka (Crain, 2014: 100). Perkembangan otak anak dalam masa peka telah mencapai 80\% (Vinayastri, 2015: 36). Berdasarkan hal tersebut perkembangan kognitif anak usia dini telah mencapai lebih dari setengah dari perkembangan secara keseluruhan. Hal ini akan berdampak bagi anak dalam menyerap segala informasi yang ada di lingkungan sekitar, baik secara sengaja maupun tidak sengaja.

Pemberian stimulasi yang baik dari lingkungan juga mampu meningkatkan perkembangan anak menjadi lebih optimal karena masa keemasan hanya dialami oleh anak satu kali dalam hidupnya. Hal ini ditunjukkan dalam hasil penelitian yang menunjukkan bahwa terdapat hubungan positif dengan kekuatan kuat dan statistic signifikan ( $p=0,001 ; C I$ $95 \% ; \mathrm{OR}=3,37$ ) antara pemberian stimulasi tumbuh kembang dengan perkembangan anak usia 1-3 tahun (Hati \& Lestari, 2016: 47). Berdasarkan hal tersebut, pemberian stimulasi pada aspek perkembangan anak akan memberikan dampak pada perkembangan anak yang optimal (Siswina dkk., 2016: 29).

Aspek perkembangan yang perlu diberikan stimulasi beragam jenisnya. Aspek tersebut meliputi aspek fisik motorik, kognitif, dan sosial emosional. Pemberian stimulasi pada anak harus memperhatikan pencapaiannya supaya perkembangan anak sesuai dengan usianya. Tugas pencapaian perkembangan anak khususnya di Indonesia dapat dilihat pada STPPA khususnya dilampiran 1 (Kementerian Pendidikan dan Kebudayaan Republik Indonesia, 2014: 21-31). Tugas pencapaian perkembangan anak pada aspek fisik motorik anak usia 5-6 tahun yaitu memiliki berat badan sekitar 18,7-20,6 kg, tinggi badan sekitar 110-116 $\mathrm{cm}$, dapat menggunting sesuai pola, mampu menggunakan alat tulis, melompat, meloncat, melakukan gerakan senam atau tarian, dan, berjalan di atas papan titian (Yuriastien dkk., 2009: 3; Allen \& Marotz, 1998: 105-106; \& Kementerian Pendidikan dan Kebudayaan Republik Indonesia, 2014: 21-22). Aspek perkembangan kognitifnya antara lain yaitu mengenal bentuk geometri, memhami perbedaan dan persamaan ukuran, mengenal huruf, mengenal warna, menyebut lambang bilangan 1-20, dan mampu mengklasifikan (Kementerian Pendidikan dan Kebudayaan Republik Indonesia, 2014: 24-26; Y. N. Sujiono dkk., 2014: 2.16; \& Tadjuddin, 2014: 156-157). Aspek terakhir yaitu aspek sosial dan emosional yang meliputi menghargai, menunjukkan rasa kasih sayang terhadap orang lain, mengendalikan emosi yang dirasakan berbagi, empati, bermain dengan teman sebaya, dan kooperatif (Abu Taleb \& AlZoubi, 2015: 899; Allen \& Marotz, 1998: 142; Jukes dkk., 2018: 162; \& Kementerian Pendidikan dan Kebudayaan Republik Indonesia, 2014: 28-29).

Semua aspek perkembangan anak harus distimulasi. Pemberian stimulasi ini tidak hanya dilimpahkan kepada sekolah melainkan di rumah juga ada pemberian stimulasi. Hal ini sesuai dengan tri pusat pendidikan yang menjelaskan bahwa rumah, sekolah, dan masyarakat saling bersinergi (Siswoyo dkk., 2013: 136). Oleh sebab itu, penting adanya kerjasama diantara tiga pusat tersebut supaya perkembangan anak menjadi optimal. Keberhasilan perkembangan pada anak usia dini menentukan perkembangan anak di tahap berikutnya (Farida, 2018: 21).

Sesuai dengan hasil wawancara, anak mengalami kendala ketika ingin bersekolah. Ini disebabkan orangtua tidak ingin meninggalkan anaknya di rumah Magelang sehingga kemanapun orangtuanya pergi pasti diajaknya. Padahal, anaknya sering merengek ingin pergi ke sekolah. Berbeda dengan ketiga kakaknya sebelumnya yang tetap bisa bersekolah namun tidak ada pendampingan dari orangtua.

Berdasarkan studi pendahuluan yang telah dilakukan pada salah satu orangtua tentara nasional Indonesia perlunya dilakukan penelitian mengenai pola asuh yang diterapkan. Demikian, peneliti mengkaji tentang "Penerapan pola asuh orangtua tentara nasional Indonesia terhadap perkembangan anak usia 5-6 tahun." Tujuan dari penelitian ini adalah memberikan informasi penerapan pola asuh orangtua Tentara Nasional Indonesia dan 
pengaruh pola asuh yang diterapkan terhadap perkembangan anak. Hasil penelitian ini diharapkan orangtua Tentara Nasional Indonesia memahami dampak pola asuh yang diterapkan pada anak supaya anak dapat tumbuh dan berkembang secara optimal.

\section{METODOLOGI}

Jenis penelitian yang digunakan yaitu dengan menggunakan pendekatan kualitatif dengan metode analisis deskriptif yang bertujuan untuk menggambarkan fenomena yang ada, yang terjadi saat itu, maupun di masa lampau (Sukmadinata, 2010: 54). Penelitian ini mendeskripsikan pola asuh pada anak di lingkungan keluarga militer. Oleh sebab itu, data yang diperoleh akan berbentuk penjelasan yang menggambarkan keadaan tersebut. Penelian ini dilakukan di keluarga militer dan TK Negeri Pembiana yang beralamatkan di daerah Perumnas Rambutan X Kalinegoro, Mertoyudan, Jawa Tengah. Subjek penelitian yaitu keluarga militer yang tinggal di daerah perumnas dan ayahnya tidak dinas di lingkungan tempat tinggal. Subjek yang digunakan dalam penelitian yaitu satu orang anak yang tinggal di lingkup keluarga militer. Pengambilan data dilakukan selama bulan April yaitu dari tanggal 1 - 30 April 2020.

Sumber data yang digunakan yaitu sumber data primer dan sumber data sekunder (Suryabrata, 1978: 93). Sumber data primer yaitu dari ayah dan ibu. Sumber data sekunder yaitu rapor perkembangan anak dan guru. Sumber data telah dirumuskan maka menentukan teknik pengumpulan yang akan digunakan dalam penelitian. Teknik pengumpulan data adalah cara yang digunakan peneliti untuk memperoleh informasi yang dibutuhkan (Sugiyono, 2015: 311). Cara yang digunakan untuk memperoleh informasi mengenai pola asuh yang diterapkan di keluarga militer yaitu menggunakan wawancara, observasi, dan dokumentasi.

Wawancara terbagi menjadi tiga macam yaitu wawancara terstruktur, wawancara semi terstruktur, dan wawanacara tidak terstruktur (Sugiyono, 2015: 310-320; Anggito \& Setiawan, 2018: 87). Namun, peneliti memilih menggunakan wawancara dengan jenis semi terstruktur. Jenis wawancara ini termasuk dalam in depth interview maka wawancara yang digunakan bisa mendalam dan terarah sesuai dengan kebutuhan yang diperlukan.

Observasi yang digunakan yaitu observasi non partisipan yang mana peneliti tidak terlibat aktif dalam suatu aktivitas pada yang diamati melainkan hanya berperan sebagai pengamat independen (Sugiyono, 2015: 204). Observasi dilakukan pada saat anak melakukan kegiatan sehari-hari dan ketika proses pembelajaran di rumah. Dokumentasi merupakan catatan sebuah peristiwa yang telah berlalu. Dokumen ini bisa berupa gambar, tulisan, dan karya-karya (Sugiyono, 2015: 329). Penelitian ini menggunakan dokumentasi berupa foto maupun rapor perkembangan anak.

Keabsahan data pada penelitian ini merupakan konsep kesahihah (validitas) dan keandalan (reabilitas). Adapun beberapa kriteria yang digunakan untuk memeriksa keabsahan data yaitu derajat kepercayaan, keteralihan, kebergantuangan, dan kepastian (Moleong, 2007: 324). Derajat kepercayaan ini dapat diuji dengan teknik triangulasi dan kecukupan referensial. Keabsa han data dari ini yaitu dengan melakukan triangulasi dengan sumber. Maksud dari triangulasi sumber adalah membandingkan dan mengecek kembali derajat kepercayaan suatu informasi yang diperoleh melalui waktu dan alat yang berbeda dalam penelitian kualitatif (Moleong, 2007: 29). Triangulasi sumber yang dilaksanakan pada penelitian ini yaitu membandingkan hasil wawancara dengan isi dokumen yang berkaitan.

Teknik yang digunakan dalam penelitian ini yaitu menggunakan teknik analisis data Model Milles dan Huberman. Teknik ini dilakukan saat berlangsungnya pengumpulan data dan setelah selesai pengumpulan data. Analisis data dilakukan dengan menggunakan tiga alur kegiatan yang terjadi secara bersamaan yaitu reduksi data (data reduction), penyajian data (data display), simpulan/verifikasi (conclusion drawing/verification) (Sugiyono, 2015: 338-345). Berikut tahapan penelitian yang dilakukan oleh peneliti. 


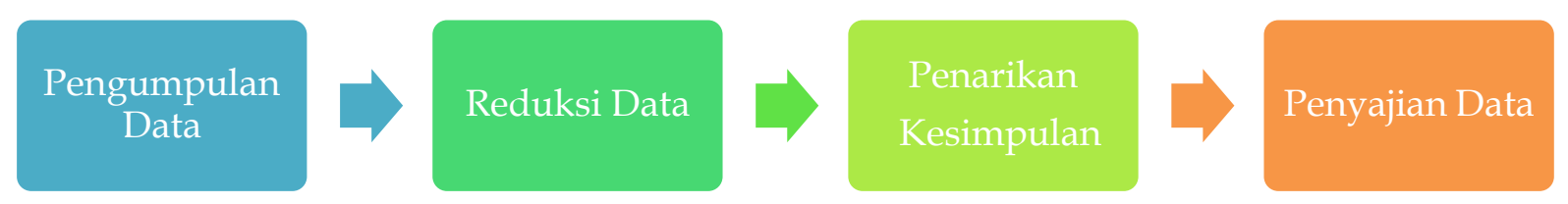

Gambar 1. Tahapan Penelitian

Reduksi data dalam penelitian ini dilakukan dengan merangkum, memilih hal-hal yang pokok, dan memfokuskan pada hal-hal yang penting yang dapat memberikan data mengenai pola asuh yang diterapkan di keluarga militer dan perkembangan anak. Ketika telah merangkum maka peneliti akan menyajikan data. Penyajian data dalam penelitian ini dilakukan dalam bentuk teks yang bersifat naratif mengenai pola asuh yang diterapkan di keluarga militer dan perkembangan anak (Sugiyono, 2015: 341). Tahap terakhir yaitu penarikan kesimpulan. Kesimpulan dalam penelitian ini berupa deskripsi pola asuh yang diterapkan di keluarga militer dan perkembangan anak. Teknik analisis data dilakukan secara interkatif dan secara terus menerus hingga datanya telah jenuh.

\section{HASIL DAN PEMBAHASAN}

Orangtua tentara nasional sering disebut juga dengan keluarga militer. Umumnya militer dididik dengan tegas, keras, dan disiplin. Hal ini disebabkan seorang angkatan tugasnya berada di medan perang.

Anggota militer juga perlu membutuhkan dukungan terutama keluarga. Terutama anggota militer yang mengikuti tugas dinas di luar. Hal ini menyebabkan keluarga tidak bisa berkumpul layaknya keluarga pada umumnya. Jadi, sebagian besar anggota militer yang mengikuti dinas luar maka jarang bertemu dengan istri, anak, bahkan keluarga yang lain. Sesuai dengan hasil wawancara keluarga militer yang menjadi subjek penelitian juga termasuk jarang bertemu, meskipun ayahnya seorang komandan. Jarang bertemunya ini dikarenakan anak bersekolah di Magelang. Walaupun anak bersekolah di Magelang tetapi anak sering ikut kemana pun ibunya pergi.

Istri seorang anggota militer ini harus mendukung suami dalam menjalankan tugasnya. Oleh sebab itu, istri harus bolak balik antara Kalimantan dan Magelang supaya semua kewajibannya dapat terpenuhi. Kewajiban menjadi seorang istri prajurit dan kewajiban menjadi seorang ibu.

... memang benar menjadi istri salah satu anggota militer harus medampingi suaminya bahkan mendukung disetiap tugas yang diberikan oleh pimpinan... saya hamper 3 bulan sekali atau menyesuaikan situasi untuk bolak balik Kalimantan ke Magelang dan selalu membawa anak saya... (kutipan wawancara dengan ibu $A G$ )

Adanya pemenuhan dua kewajiban ini mempengaruhi pola asuh dan perkembangan anak. Padahal, pola asuh ini harus dilakukan oleh seorang suami dan istri. Terkadang istri seorang prajurit sering mengalami kesulitan menggantikan posisi ayahnya dalam merawat anak (Damayanti dkk., 2016: 127).

Pola asuh merupakan pola interaksi yang antara orangtua dengan anak untuk mengontrol kehidupan anak (Baumrind, 1991: 60). Berdasarkan hasil wawancara, observasi, dan dokumentasi yang telah didapatkan sesuai dengan rumusan masalah. Hasil penelitian menunjukkan bahwa pola asuh yang diterapkan pada keluarga militer ini merujuk pada pola asuh model authoritarian. Pola asuh ini merupakan pola asuh yang memberikan kehangatan antara orangtua dengan anak (Baumrind, 1991: 62). Pola asuh ini memadukan antara punishment dan reward. Sejalan dengan hasil penelitian yang menunjukkan bahwa orangtua di keluarga militer akan menerapkan system kemiliteran dan tetap adanya komunikasi dua arah. Ini ditunjukkan ketika orangtua dan anak melakukan penetapan aturan yang dilakukan secara 
bersama melanggar aturan yang dibuat bersama (Baumrind, 1966). Adanya aturan yang dibuat bersama memberikan tanggungjawab dan perilaku tertib pada anak. Selain adanya komunikasai dua arah, orangtua akan memberikan punishment pada anak. Punishment ini dilakukan ketika anak melanggar aturan yang telah dibuat dan adanya batasan ketika memberikannya. Namun, orangtua memberikan reward pada anak jika telah melaksanakan aturan.

... saya akan mengkritik anak perbuatan anak saya maupun yang baik dan buruk. Kalau anak saya berbuat baik tentunya saya akan memberikan pujian secara verbal contohnya seperti M adalah anak yang pintar... (kutipan wawancara dengan bapak $H$ )

... jika anak saya melakukan hal tidak baik, saya akan mengurangi kekebasan dia untuk melakukan hal yang disenanginya seperti untuk bermain gadget ataupun menggunakan ancaman... (kutipan wawancara dengan bapak $H$ )

Pola asuh yang diterapkan orangtua menciptakan ikatan emosi diantara anak dengan orangtua (Sathananthan \& Tellambura, 2002: 493). Ikatan emosi ini umumnya disebut dengan kelekatan yang dikembangkan melalui interaksi dan menimbulkan arti khusus kehidupan (Santrock, 2012: 219). Contohnya seperti orangtua yang selalu ada ketika membutuhkan kedua orangtunya. Anak merasa sedih maupun kecewa maka orangtua akan menenangkan anaknya dengan memberikan pelukan. Hubungan kelekatan yang aman pada pengasuhan dapat diprediksi kualitas hubungan sosial bermakna dan mendukung (Spruit dkk., 2020: 53).

... terkadang pulang main dengan teman atau kakaknya ekpresi ketika setelah main itu berbeda, kadang terlihat senang kadang sedih. Ya maklum anak-anak, tetapi saya juga menanyakan apa yang telah terjadi kepada anak saya dan mendengarkan ceritanya. Kalau pas anak sedih yaa dipeluk dulu baru ditanyain.. (kutipan wawancara dengan ibu AG)

Penerapan pola asuh authoritharian di keluarga militer dilatar belakangi oleh beberapa faktor yang mempengaruhinya. Sesuai dengan hasil penelitian faktor yang mempengaruhi pola asuh yaitu usia dari orangtua, status sosial ekonomi keluarga, kesesuaian gaya, jenis kelamin, dan wilayah (Hurlock, 2002: 95 \& Subakti, 2012: 9).

Faktor pertama yaitu kesesuaian gaya pola asuh yang diterapkan orangtua terdahulu. Hal ini terjadi ketika di awal memiliki anak. Namun, orangtua tidak henti-hentinya untuk belajar. Oleh sebab itu, tidak serta merta semua pola asuh orang terdahulu diterapkannya.

... awalnya ya saya belajar dari pola asuh dari orangtua saya dulu, tapi lama kelamaan setelah mengikuti kegiatan parenting tidak semua yang pola asuh yang orangtua saya terapkan saya ambil. Pilih yang sesuai karena saya juga pengen memberikan yang terbaik buat anak saya... (kutipan wawancara dengan ibu AG)

Faktor kedua yaitu usia dari orangtua. Usia ketika mendidik anak yang terakhir ini sudah matang baik secara pemikiran. Hal ini akan mempengaruhi orangtua dalam mengambil keputusan. Keputusan yang diambil seperti penerapan pola asuh yang diterapkan saat ini. Keputusan di ambil karena orangtua megikuti beberapa parenting yang diajarkan baik di kantor maupun di sekolah. Berbagai informasi yang didapatkan membuat orangtua memilih hal-hal yang baik untuk diterapkan pada anak kesayangannya.

Status ekonomi keluarga juga berkontribusi untuk mempengaruhi pola asuh. Secara teori, keluarga yang dengan status ekonomi menengah ke atas cenderung pada pola asuh authoritative. Berbanding terbalik pada keluarga yang memiliki status ekonomi menengah ke bawah yang lebih condong ke pola asuh yang keras (Hurlock, 1997: 234.). Hal ini sejalan dengan hasil penelitian yang menunjukkan di awal rumah tangga dan karir pekerjaan orangtua membuat pola asuh yang diterapkan lebih keras. Berbeda dengan pola asuh yang diterapkan sekarang lebih condong ke arah demokratis. Perbedaan ini dilatar belakangi pekerjaan ayahnya sudah mencapai puncak karirnya dan saudara kandungnya sudah beranjak dewasa semua.

... karena kakaknya sudah mandiri jadi lebih banyak perhatian ke anak saya yang terkahir ini, bapaknya juga sudah dipuncak karir (kutipan wawancara dengan Ibu AG) 
Terakhir, wilayah juga mempengaruhi dari pola asuh. Wilayah bisa berpengaruh karena ibu dan anak tinggalnya yang berpindah-pindah. Terkadang di rumah dinas di Kalimantan Selatan dan ke rumahnya sendiri di Magelang. Perbedaan wilayah ini membuat orangtua sadar akan penerapan pola asuh yang baik.

Pola asuh yang diterapkan orangtua memberikan dampak bagi anak khususnya perkembangan anak. Secara keseluruhan pola asuh authoritarian ini memberikan dampak positif. Perkembangan anak berkembang sesuai dengan tahapan anak. Meskipun anak tidak selalu berangkat ke sekolah formal.

Perkembangan anak dimulai dari masa konsepsi hingga sepanjang hidupnya (Santrock, 2011: 6). Perkembangan merupakan perubahan mental seseorang yang dialami secara bertahap dan dari kemampuan mudah ke sulit (Susanto, 2014: 21). Perkembangan anak akan berkembangan dengan pesat. Pesatnya perkembangan anak ini disebabkan anak masih dalam fase golden age (Vinayastri, 2015: 36).

Berkembangnya seorang anak dapat dilihat dari aspek perkembangannya. Aspek perkembangan anak terdiri dari fisik motorik, kognitif, sosial, dan emosional (Kementerian Pendidikan dan Kebudayaan Republik Indonesia, 2014 \& Santrock, 2011: 5). Oleh sebab itu, diperlukan stimulasi di setiap aspek perkembangan anak.

Aspek perkembangan fisik motorik ini terdiri dari dua perkembangan yaitu fisik dan motorik. Perkembangan fisik dapat terlihat secara jelas yaitu seperti perubahan bentuk dan ukuran tubuh (Fitriani, 2018: 27). Khusus anak usia dini perkembangan fisik dapat dilihat dari berat badan dan tinggi badan anak. Berat badan anak sebesar $26 \mathrm{~kg}$ dan tinggi anak 120 . Sesuai dengan table BB/TB menunjukkan bahwa diusia tersebut anak termasuk dalam kategori gemuk atau memiliki gizi yang berlebih (Yuriastien dkk., 2009: 3 \& Kesehatan \& Ikatan Dokter Anak Indonesia, 2005: 43-45). Meskipun anak dalam kategori gemuk, anak masih aktif dalam melakukan kegiatannya.

Perkembangan motorik adalah kematangan dan pengendalian gerak tubuh (Sujiono, 2016: 1.3). Perkembangan motorik dibagi menjadi dua yaitu halus dan kasar. Keterampilan motorik halus yaitu keterampilan yang menggunakan otot halus dalam melakukan aktivitas. Berdasarkan hasil observasi dan dokumentasi, keterampilan yang telah dikuasi anak yaitu menggunakan alat tulis dengan benar bahkan mampu gunting sesuai dengan pola baik lurus, zig-zag, dan melingkar. Sedangkan keterampilan kasar adalah keterampilan dalam melakukan aktivitas menggunakan otot besar. Keterampilan yang telah dikuasai anak meliputi melompat, meloncat, berjalan di atas papan titian, menangkap bola, dan mengikuti gerakan senam maupun tarian.

Aspek perkembangan berikutnya yaitu perkembangan kognitif. Perkembangan kognitif kemampuan belajar atau berfikir atau kecerdasan yaitu kemampuan untuk mempelajari keterampilan dan konsep baru, keterampilan memahami yang terjadi di lingkungannya serta kemampuan untuk menggunakan daya ingat dalam menyelesaikan soalsoal sederhana (Saghir dkk., 2016: 31). Pada usia ini perkembangan kognitif ini masih dalam tahap pra operasional atau masih dalam tahap pra berpikir (Ojose, 2008: 29-31; Saghir dkk., 2016: 74; Khairi, 2018: 24; \& Hanfstingl dkk., 2019: 1-2). Oleh sebab itu, anak belajar dari benda yang konkrit dan sederhana. Hasil dari observasi dan dokumentasi beberapa kemampuan kognitif anak sudah pada tahap perkembangan anak usianya. Anak telah mampu mengenal bentuk geometri seperti segitiga dan kotak. Meskipun pada diusia tersebut anak harus menguasai tiga bentuk geometri yaitu lingkaran, kotak, dan segitiga. Selain itu, anak telah mampu mengenal huruf alphabet meskipun tidak semua 26 huruf alphabet diketahui. Anak baru mengenali a, b, c, d, e, f, I, l, m, o, p, r, dan s. Anak juga mengenali warna primer dan sekunder. Warna yang diketahui anak yaitu merah, kuning, biru, putih, hijau, hitam, ungu, dan cokelat. Pengenalan angka anak sudah sesuai dengan tahapannya yaitu mengenal angka 1-20. Kemampuan terakhir anak juga mamapu membedakan persamaan dan perbedaan. Ketika anak sudah memahami itu maka anak mampu mengklasifikanya sesuai dengan bentuk 
warna bahkan ukuran. Contohnya seperti mengklasifikan warna lego dan mengelompokkan piring, garpu, bahkan piring.

Aspek perkembangan berikutnya yaitu aspek sosial. Perkembangan sosial merupakan proses belajar anak untuk menyesuaikan diri dengan norma, moral, dan tradisi dalam sebuah kelompok (Nurmalitasari, 2015: 104). Perkembangan ini terlihat ketika anak berinteraksi dengan lingkungannya. Hal ini ditunjukkan ketika wawancara anak memiliki teman dekat ketika di sekolah. Hubungan yang baik ini membuat ketika berangkat sekolah meraka saling jemput satu sama lain. Anak juga mampu membagi benda yang dimilikinya.

Perkembangan terakhir yaitu aspek emosi. Emosi bisa dikatakan sebagai keadaan seseorang dalam merespon suatu peristiwa (Mashar, 2015: 16). Emosi seseorang ini tidak hanya negative saja melainkan juga emosi positif. Macam emosi pada anak usia dini meliputi kasih sayang, cemas, ikatan kasih sayang, cemburu, depresi, destruktif, phobia, gembira, hipersensitivitas, impulsif, malu, marah, melamun, rasa tidak aman, stres, takut, dan tempertantrum (Sujiono \& Sujjiono, 2005: 127 \& Hurlock, 1978: 244). Hasil observasi menunjukkan anak telah mampu mengungkapkan emosi positifnya. Namun, anak ketika boneka kesayangannya diganti maupun dicuci emosinya belum terkontrol. Anak dapat memarahi orang yang didekatnya. Hal ini, juga menjadi salah satu dampak dari pola asuh yang diterapkan oleh orangtuanya (Megawangi, 2016: 173). Selain hal itu, anak mampu mengendalikan emosi negatifnya.

Kedisplinan merupakan hal penting yang ditanamkan pada anak usia dini. Kedisiplinan merupakan cara bagi anak untuk mengembangkan pengendalian diri (emadwiandr, 2013: 39). Displin juga membuat anak memiliki batasan untuk memperbaiki tingkah laku yang salah (Wantah, 2005: 140). Proses terpenting ketika menerapkan kedisiplinan yaitu anak memenuhi aturan (Woolfson, 2005: 42). Hasil wawancara dan observasi orangtua menerapkan kedisplinan pada anaknya seperti selalu menggosok gigi sebelum tidur, melaksanakan salat diawal waktu, bermain, dan makan. Tentunya mendisplinkan anak tidak mudah, maka orangtua perlu konsisten dalam menerapkan. Sejalan dengan pendapat (Coyle \& Ken, 2004: 152) yang menjelaskan bahwa konsisten merupakan aspek terpenting dalam menerapkan kedisiplinan anak.
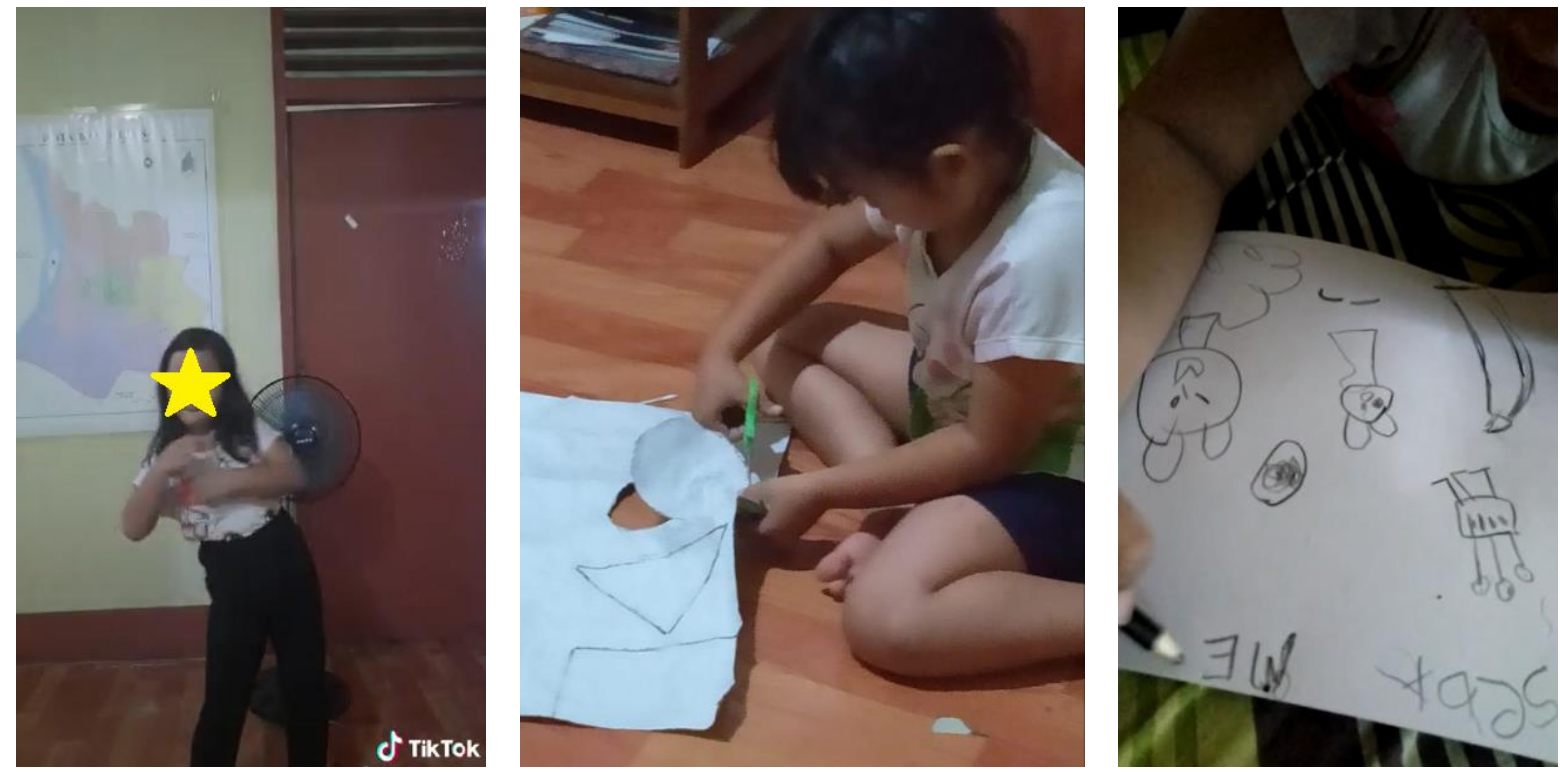

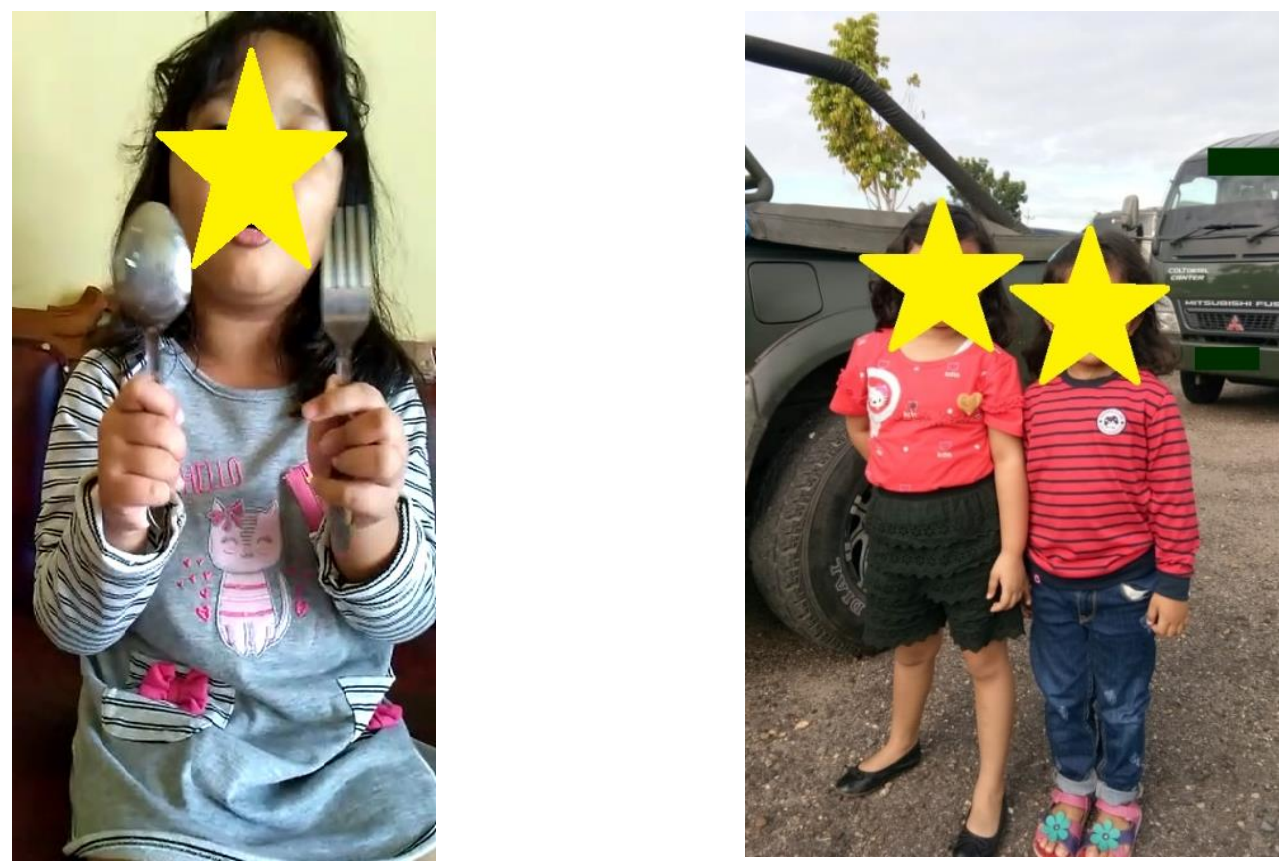

\section{Gambar 2. Perkembangan Anak}

Gambar di atas menunjukkan beberapa bukti perkembangan anak. Aspek perkembangan yang terdapat pada gambar tersebut adalah perkembangan motorik, perkembangan kognitif, dan perkembangan sosial.

Semua perkembangan anak berkembangan dipengaruhi oleh beberapa faktor (Chandra, 2011: 12 ; Chamidah, 2009: 85). Faktor internal merupakan faktor secara genetik. Selain itu, faktor eksternal merupakan faktor dari luar genetik misalnya gizi dan stimulasi. Akan tetapi, perkembangan anak berkembang secara optimal dipengaruhi dari faktor eksternal khususnya pemberian stimulasi yang baik.

\section{SIMPULAN}

Pola asuh yang digunakan oleh orangtua Tentara Nasional Indonesia adalah pola asuh authoritarian. Pola asuh ini menjelaskan bahwa pola asuh menggunakan arahan terhadap anak dan komunikasi dua arah sehingga adanya kehangatan di dalam keluarga. Kehangatan dari pola asuh authoritarian memberikan dampak positif bagi perkembangan anak. Perkembangan anak berkembangan sesuai dengan tahapan usia anak. Hal ini terlihat aspek perkembangan anak yang meliputi aspek fisik motorik, kognitif, sosial, dan emosi.

\section{UCAPAN TERIMA KASIH}

Peneliti memanjadkan puji syukur kepada Allah SWT atas berkat rahmat dan karuniaNya sehingga peneliti dapat melaksanakan penelitian dan menyelesaikan karya ilmiah ini dengan baik. Penulisan karya ilmiah ini dapat diselesaikan tidak lepas dari bantuan dan kerjasama dengan pihak lain. Dosen pembimbing saya yang telah memberikan arahan dan masukan secara komprehensif. Orangtua yang telah memberikan dukungan baik doa, motivasi, dan materi. Keluarga anggota tentara nasional Indonesia yang telah membantu dalam mengambil data.

\section{DAFTAR PUSTAKA}

Abu Taleb, T. F., \& AlZoubi, R. R. (2015). Jordanian mothers' perceptions of their children's social competence: an examination of family factors and demographic variables. Early Child Development and Care, 185(6), 895-908. https:/ / doi.org/10.1080/03004430.2014.963067

Allen, Eileen; Marotz, L. (2003). Developmental Profiles Pre-Birth Through Twelve. 4. 
Anggito, A., \& Setiawan, J. (2018). Metode penelitian kualitatif. CV Jejak.

Baumrind, D. (1966). Effects of Authoritative Parental Control on Child Behavior. Child Development, 37(4), 887. https://doi.org/10.2307/1126611

Baumrind, D. (1991). The Influence of Parenting Style on Adolescent Competence and Substance Use. The Journal of Early Adolescence, 11(1), 56-95. https:// doi.org/10.1177/0272431691111004

Chamidah, A. N. (2012). Deteksi Dini Gangguan Pertumbuhan dan Perkembangan Anak. JPK (Jurnal Pendidikan Khusus), 4(3). https://doi.org/10.21831/jpk.v4i3.789

Chandra, S. M. Y. (2011). Tinjauan tentang anak, pertumbuhan dan perkembangan anak usia dini, iq, eq, cq dan konsep ruang bagi anak.

Coyle, J. (2004). Mendidik anak menjadi pemenang. Pustaka tangga.

Crain, W. (2007). Teori Perkembangan Konsep dan Aplikasi. In Pustaka Pelajar (Vol. 45, Issue 1). Pustaka Belajar. https:// doi.org/10.7202/1016404ar

Darman, R. A. (2017). Mempersiapkan Generasi Emas Indonesia Tahun 2045 Melalui Pendidikan Berkualitas. Jurnal Edik Informatika, V3.i2, 73-87. https://doi.org/http://dx.doi.org/10.22202/jei.2017.v3i2.1320

Effiana Yuriastien, S.Psi, Psikologi, Daisy Prawitasari, S.Psi, Psikologi, Ayu Bulan Febry K.D, S. K. (2009). Games Therapy untuk Kecerdasan Bayi \& Balita. Wahyu Media.

Elisabet, H. (2010). Psikologi Perkembangan Suatu Pendekatan Sepanjang Rentang Hidup. In Erlangga (lima). Erlangga.

Erawati, E. (2018). Meningkatkan Kedisiplinan Anak Melalui Penggunaan Reinforcement Secara Variatif Pada Anak Kelompok B1 Taman Kanak-Kanak Negeri Pembina Kepahiang. Ilmiah Potnsia, 3(1), 36-43. https:/ / doi.org/10.1017/CBO9781107415324.004

Erna Damayanti, F., Ratnawati, R., \& Imavike Fevriasanty, F. (2016). Pengalaman istri tentara (tniad) yang tinggal di batalyon saat suami bertugas di daerah rawan konflik. Jurnal Ilmu $\begin{array}{llll}\text { Keperawatan (Journal of Nursing Science), 4(2), 127-144. } & \end{array}$ https:// doi.org/10.21776/ub.jik.2016.004.02.4

Farida, F. (2018). Upaya Mengoptimalkan Perkembangan Anak Usia Dini. ThufuLA: Jurnal Inovasi Pendidikan Guru Raudhatul Athfal, 2(1), 1. https://doi.org/10.21043/thufula.v2i1.4263

Fitriani, R. (2018). Perkembangan Fisik Motorik Anak Usia Dini. Jurnal Golden Age Hamzanwadi University, 3(1), 25-34.

Gabrieli, P., Mgonda, N. L., Nsolezi, F. S., Jeremiah, G., Tibenda, J. L., \& Bub, K. L. (2018). “Respect is an Investment": Community Perceptions of Social and Emotional Competencies in Early Childhood from Mtwara, Tanzania. Tanzania. Global Education Review, 5(2), 160-188.

Hanfstingl, B., Benke, G., \& Zhang, Y. (2019). Comparing variation theory with Piaget's theory of cognitive development: more similarities than differences? Educational Action Research, 27(4), 511-526. https:// doi.org/10.1080/09650792.2018.1564687

Hati, F. S., \& Lestari, P. (2016). Pengaruh Pemberian Stimulasi pada Perkembangan Anak Usia 1236 Bulan di Kecamatan Sedayu, Bantul. Jurnal Ners Dan Kebidanan Indonesia, 4(1), 44. https://doi.org/10.21927/jnki.2016.4(1).44-48

Hurlock, B. E. (1978). Perkembangan anak (Jakarta). Erlangga.

Hurlock, B. E. (2002). Perkembangan anak. Erlangga.

Hurlock, B. E. (2012). Review Of Children, Growth And Development Of Early Age, IQ, EQ, CQ And Space Concepts For Children. Tinjauan Tentang Anak, Pertumbuhan, Dan Perkembangan, 9-28.

Kementerian Pendidikan dan Kebudayaan Republik Indonesia. (2014). Standar Isi Tentang Tingkat Pencapaian Perkembangan Anak. Peraturan Menteri Pendidikan Dan Kebudayaan Republik Indonesia Nomor 137 Tahun 2014, 1-31.

Khairi, H. (2018). Karakteristik Perkembangan Anak Usia Dini dari 0-6 Tahun. Jurnal Warna, 2(2), 15-28. https://ejournal.iaiig.ac.id/index.php/warna/article/view/87

Mashar, R. (2011). Emosi Anak Usia Dini dan Perkembangannya. Kencana.

Megawangi, R. (2016). Pendidikan karakter: solusi yang tepat untuk membangun bangsa. 173.

Moleong, L. J. (2007). Metodelogi penelitian kualitatif. Remaja Rosdakarya.

Nurmalitasari, F. (2015). Perkembangan Sosial Emosi pada Anak Usia Prasekolah. Buletin Psikologi, 23(2), 103. https:// doi.org/10.22146/bpsi.10567 
Ojose, B. (2008). Piaget and Maths. The Matematics Educator, 18(1), 26-30.

Priambudi, I., Purnama, H., \& Prasetio, A. (2015). Konsep Diri Atas Profesionalisme Anggota Tentara Nasional Indonesia. Jurnal Telekomunikasi, 2, 2188-2196.

RI, K. K. (2014). Pedoman Pelaksanaan Stimulasi, Deteksi dan Intervensi Dini Tumbuh Kembang Anak Ditingkat Pelayanan Kesehatan Dasar. Depkes RI dan IDAI.

RI, K. P. dan K. (2003). Penjelasan Undang-Undang RI Nomor 20 Tahun 2003 Tentang Sistem Pendidikan Nasional (Vol. 4, p. 147).

Richard, W. (2005). No Mengapa anakku begitu: Panduan Praktis Menuju Pola Asuh Positif. Erlangga.

Saghir, A., Hussain, A., Batool, A., Sittar, K., \& Malik, M. (2016). Play and Cognitive Development: Formal Operational Perspective of Piaget's Theory. Journal of Education and Practice, 7(28), 72-79. https:// doi.org/10.1017/CBO9781107415324.004

Sanjiwani, N. L. P. Y., \& Budisetyani, I. G. A. P. W. (2014). Pola Asuh Permisif Ibu dan Perilaku Merokok Pada Remaja Laki-Laki di Sma Negeri 1 Semarapura. Jurnal Psikologi Udayana, 1(2), 344-352. https:// doi.org/10.24843/jpu.2014.v01.i02.p13

Santrock, J. (2012). Perkembangan masa hidup jilid II (edisi ke 13). (13th ed., pp. 219; 5). Erlangga.

Santrock, J. W. (2011). Child development (13th ed.). McGraw-Hill Companies.

Sardiman, A. M. (2008). Interaksi dan Motivasi Belajar Mengajar, cet. 16, Jakarta: PT. Raja Grafindo Persada, 51.

Sathananthan, K., \& Tellambura, C. (2002). Partial transmit sequence and selected mapping schemes to reduce ICI in OFDM systems. IEEE Communications Letters, 6(8), 313-315. https:// doi.org/10.1109/LCOMM.2002.802067

Siswina, T., Shahib, N., \& Rasyad, A. S. (2016). Terhadap Perkembangan Kecerdasan Anak Usia 36 Tahun. Jurnal Ilmiah Bidan, 1(2), 27-33.

Siswoyo, D., Sulistyono, T., Dardiri, A., Rohman, A., Hendrowibowo, L., \& Sidharto, S. (2013). Ilmu pendidikan. UNY Press.

Spruit, A., Goos, L., Weenink, N., Rodenburg, R., Niemeyer, H., Stams, G. J., \& Colonnesi, C. (2020). The Relation Between Attachment and Depression in Children and Adolescents: A Multilevel Meta-Analysis. In Clinical Child and Family Psychology Review (Vol. 23, Issue 1, pp. 54-69). Springer US. https:// doi.org/10.1007/s10567-019-00299-9

Sri Asri, A. (2018). Hubungan Pola Asuh Terhadap Perkembangan Anak Usia Dini. Jurnal Ilmiah Sekolah Dasar, 2(1), 1. https:// doi.org/10.23887/jisd.v2i1.13793

Subakti, E. . (2012). Parenting anak-anak. Elex Media Komputindo.

Sugiyono. (2018). Metode Penelitian Pendidikan (Pendekatan Kuantitatif, Kualitatif, dan RED). Alfabeta.

Sujiono. (2016). Metode pengembangan fisik. Universitas Terbuka.

Sujiono, B., \& Sujjiono, Y. (2005). Mencerdaskan perilaku anak usia dini. Elex Media Komputindo.

Sujiono, Y. N., Zainal, O. R., Tampiomas, E. S., Rahayu, A. Y., \& Syamsiatin, E. (n.d.). Metode Pengembangan Kognitif. Universitas Terbuka.

Sukmadinata, N. . (2010). Metode penelitian pendidikan. Remaja Rosdakarya.

Suryabrata, S. (1978). Metode penelitian. Rajawali.

Susanto, A. (2013). Teori Belajar dan Pembelajaran di SD. In Biomass Chem Eng (Vol. 49, Issues 236). Kencana Prenada Media.

Tadjuddin, S. N. (2014). Meneropong perkembangan anak usia dini persepektifal-qur'an. Herya Medika. Tridhonato, \& Agency, B. (2014). Mengembangkan pola asuh demokratis. Elex Media Komputindo. Vinayastri, A. (2015). Perkembangan Otak Anak Usia Dini. Jurnal Ilmiah WIDYA, 3(1), 33-42.

Wantah, M. J. (2005). Pengembangan Disiplin dan Pemebentukan Moral Pada AUD. Departeen Pendidikan Nasional. 